\title{
Description of Waste Management of COVID-19 Patients without Symptoms in Self-Isolation Period Mamuju District
}

\author{
Abdul Ganing ${ }^{1}$, Haeranah Ahmad ${ }^{2}$, Ridhayani Adiningsih ${ }^{3}$, Sri Wahyuni ${ }^{4}$, \\ Rahmat Haji Saeni ${ }^{5}$ \\ ${ }^{1-3}$ Department of Environmental Health Health Polytechnic Ministry of Health Mamuju \\ ${ }^{4}$ Department of Nutrition, Health Polytechnic, Ministry of Health, Mamuju \\ Corresponding Author: Rahmat Haji Saeni
}

DOI: https://doi.org/10.52403/ijrr.20220243

\begin{abstract}
Background: COVID-19 (coronavirus disease 2019) is a disease caused by a new type of coronavirus, namely Sars-CoV-2, which was first reported in Wuhan, China. In Indonesia May 2020, the death toll is continuing. Globally, there were 4,170,424 cases of COVID-19 with 287,399 deaths. Citing the recap of the COVID19 data from the West Sulawesi Provincial Health Office, as of February 6, 2021, the cumulative number of positive COVID-19 cases was 4,380, an increase of $73 \%$.

Purpose: This research is to find out the description of Waste Management of Covid-19 Patients Without Symptoms (OTG) During the Independent Isolation Period of Mamuju District.

The Research Method used in this research is the descriptive research method. The location of the research was carried out in Mamuju District. The number of samples in this study was 30 respondents. The data collection technique used was interviewed using a questionnaire.

Results: The results showed that there was waste management that was not by the standards. This is due to the lack of facilities in the patient's home and lack of knowledge.

Conclusion: Waste management by asymptomatic Covid-19 sufferers does not meet waste processing standards.
\end{abstract}

Keywords: Covid 19, isolation, waste

\section{BACKGROUND}

The world health problem that is currently in the spotlight and is very important to get the attention of health scientists and the general public is disease due to the coronavirus. Corona Virus Disease-19 or more popularly known as COVID-19 has been designated by WHO (World Health Organization) or the World Health Organization as a Public Health Emergency of World Concern (KMMD) on January 30, 2020, and on March 11, 2020, WHO has declared COVID-19 a pandemic[1].

In early 2020, the world was shocked by an outbreak of new pneumonia that started in Wuhan, Hubei Province, which then spread rapidly to more than 190 countries and territories. This outbreak was named coronavirus disease 2019 (COVID19) caused by Severe Acute Respiratory Syndrome Coronavirus-2 (SARS-CoV-2). The spread of this disease has had a wide social and economic impact. There is still a lot of controversy surrounding this disease, including aspects of diagnosis, treatment, and prevention. Therefore, we conducted a review of studies related to COVID-19 which have been widely published since the beginning of 2020 and then until the end of March 2020.

The first COVID-19 reported in Indonesia on March 2, 2020, was two cases. 
Data on March 31, 2020, showed that there were 1,528 confirmed cases and 136 deaths.10The COVID-19 mortality rate in Indonesia is $8.9 \%$, this figure is the highest in Southeast Asia. Indonesia is one of the countries affected by the COVID-19 pandemic. Cases of the spread of COVID19 have spread to 350 regencies/cities in 34 provinces. A total of 12,776 people were confirmed positive, 2,381 people have recovered and 930 people have died as of May 2020 (GTPP COVID-19: 2020).

Currently, the number of asymptomatic people (OTG) is quite large, therefore the handling of medical waste for OTG patients must also be considered, for asymptomatic patients undergoing isolation in hospitals, of course, there will be no problems because the handling of medical waste has special treatment from the home. sick, but what needs to be considered is for OTG patients who are in self-isolation at home. How to handle medical waste during self-isolation at home.

\section{MATERIALS AND METHODS}

This type of research is an observational study using a descriptive approach. This study describes waste management for people with Covid 19 who have no symptoms. This research was conducted using a questionnaire. The implementation is carried out by following very strict protocol procedures

\section{RESULTS}

Table 1. Distribution of Respondents Characteristics Based on Gender And Age Group

\begin{tabular}{|c|c|c|}
\hline \multirow{2}{*}{ Characteristics } & \multicolumn{2}{c|}{ Frequency } \\
\cline { 2 - 3 } & $\mathbf{n}$ & \% \\
\hline Gender & 7 & 23.3 \\
\hline Man & 23 & 76.7 \\
\hline Woman & \multicolumn{2}{|}{} \\
\hline Age group & 22 & 73.3 \\
\hline $17-25$ years & 8 & 26.7 \\
\hline $26-35$ years old
\end{tabular}

Based on table 1 above, it can be seen that the respondents who are male are $23.3 \%$, while female respondents are $76.7 \%$. Respondents with the age group of 17-25 years were $73.3 \%$, while the age group of 25-35 years was $26.7 \%$.

Table 2 Distribution of Infectious Waste Used When Doing Self-Isolation

\begin{tabular}{|l|c|c|}
\hline \multirow{2}{*}{ Types of medical waste } & \multicolumn{3}{c|}{ Frequency } \\
\cline { 2 - 3 } & $\mathbf{n}$ & $\mathbf{\%}$ \\
\hline Syringe & 1 & 3.3 \\
\hline Used Rapid Test & 1 & 3.3 \\
\hline Tissue & 19 & 63.3 \\
\hline Cotton & 2 & 6.7 \\
\hline Gloves & 3 & 10.0 \\
\hline Mask & 30 & 100.0 \\
\hline Bandage & 7 & 23.3 \\
\hline Cardboard/Plastic/Glass Food Packaging & 30 & 100.0 \\
\hline
\end{tabular}

Based on table 2 above, it can be seen that the most infectious waste is masks and cardboard/plastic/packaged food cups, each of which is $100 \%$. Meanwhile, the least infectious waste was syringed and used rapid tests, which was $3.3 \%$.

Table 3 Distribution of Infectious Waste Management When Doing Self-Isolation

\begin{tabular}{|c|c|c|c|c|}
\hline \multirow{3}{*}{ Infectious Waste } & \multicolumn{4}{|c|}{ Frequency } \\
\hline & \multicolumn{2}{|c|}{ Yes } & \multicolumn{2}{|c|}{ Not } \\
\hline & $\mathrm{n}$ & $\%$ & $\mathbf{n}$ & $\%$ \\
\hline $\begin{array}{l}\text { Syringes, infusion kits, and used rapid test kits __ insert them in one of the existing cardboard/plastic } \\
\text { containers }\end{array}$ & 2 & 6.7 & 28 & 93.3 \\
\hline Gauze, tissue, and cotton _ join with other family members & 22 & 73.3 & 8 & 26.7 \\
\hline $\begin{array}{l}\text { Gauze, tissue, and cotton are put in a yellow bag or special bag and put in a closed trash can separate from } \\
\text { the waste of other family members }\end{array}$ & 3 & 10.0 & 27 & 90.0 \\
\hline $\begin{array}{l}\text { The rest of the food ingredients and packaged food containers are put into one of the existing } \\
\text { cardboard/plastic containers }\end{array}$ & 30 & 100.0 & 0 & 0.0 \\
\hline
\end{tabular}

Based on table 3 above, it can be seen that the syringe, infusion device, and former respondent's rapid test kit were put in one of the existing cardboard/plastic containers by $6.7 \%$. while those who are not as much as $93.3 \%$. The gauze, tissue, and cotton of the respondents were combined with the waste of other family members, which was $73.3 \%$, while those that were not were $26.7 \%$. The gauze, tissue, and cotton of the respondents were put in yellow bags or special bags and put in a closed trash can 
separate from the waste of other family members, which was $10.0 \%$, while those that were not were $90.0 \%$. The rest of the respondent's food ingredients and packaged food containers are put in one of the existing cardboard/plastic containers, which is $100.0 \%$.

Table 4 Distribution of Gloves and Waste Handling Methods Masks When Doing Self-Isolation
\begin{tabular}{|l|c|c|c|c|}
\hline \multirow{2}{*}{ Gloves and Mask } & \multicolumn{4}{c|}{ Frequency } \\
\cline { 2 - 5 } & \multicolumn{2}{|c|}{ Yes } & \multicolumn{2}{c|}{ Not } \\
\cline { 2 - 5 } & $\mathbf{n}$ & $\mathbf{\%}$ & $\mathbf{n}$ & $\mathbf{\%}$ \\
\hline Gloves behind after use & 2 & 6.7 & 28 & 93.3 \\
\hline Gloves and masks are damaged by scissors and then folds & 20 & 66.7 & 10 & 33.3 \\
\hline Gloves and masks are disinfected & 1 & 3.3 & 29 & 96.7 \\
\hline Gloves and mask Put in a waste bag, close tightly then mark & 0 & 0.0 & 30 & 100.0 \\
\hline Waste Gloves and masks combined with other family members' trash & 29 & 96.7 & 1 & 3.3 \\
\hline
\end{tabular}

Based on table 4 above, it can be seen that the respondent's gloves were turned over after being used, which was $6.7 \%$, while those that were not turned over after being used were $93.3 \%$. Respondents' gloves and masks were damaged by cutting and then folded by $66.7 \%$, while respondents who did not damage were $33.3 \%$. Respondents who did disinfection of gloves and masks were $3.3 \%$, while respondents who did not disinfect were $96.7 \%$. The respondent's gloves and masks are put in a waste bag, tightly closed then put a mark of $0.0 \%$, while the respondent's gloves and masks are not put in a waste bag, close tightly and then put a mark of $100.0 \%$. The respondent's gloves and masks were combined with the waste of other family members by $96.7 \%$,

\section{DISCUSSION}

Regulation of the Minister of Environment and Forestry of the Republic of Indonesia No. 56 of 2015 concerning the management of hazardous and toxic waste, contains the reduction and sorting, storage, transportation, processing, and destruction (hoarding or burial).[2]. In waste management, several conditions must be considered so that it does not become a medium that can damage the environment or become a source of infection, especially related to waste.[3]toxic and dangerous.

Handling of waste, especially medical waste in Indonesia, has not been adequate. Apart from being caused by many sources of routine medical waste generation (Hospitals, Laboratory Clinics) it also includes waste generated by households[4]. Another factor that influences the management of medical waste is the inadequate facilities available[5].

Knowledge is the basis that influences a person's behavior in responding to something[6]. In other words, knowledge will contribute positively to one's behavior. Likewise for waste treatment, both medical waste and household waste. Even people who have good knowledge of waste management have reached the separation stage[7].

One's knowledge and attitude towards medical waste management are very important, moreover, there is a relationship between knowledge and attitude of medical waste management to health. The factor that can contribute to one's knowledge is one's level of education. In general, someone who has a good level of knowledge will pay attention to everything around him, including keeping the environment clean and healthy.[8]. Therefore, the knowledge factor about medical waste is very important to be instilled in everyone who will carry out waste disposal[9].

Acknowledgement: None

Conflict of Interest: None

Source of Funding: None 


\section{REFERENCES}

1. Kemenkes RI, Pedoman Pencegahan Dan Pengendalian Coronavirus Disease, vol. 9, no. 2. Jakarta: Kementerian Kesehatan RI, 2020.

2. Kementerian Lingkulingkungan hidup, Peraturan Menteri Lingkungan Hidup Dan Kehutanan Republik Indonesia. 2015.

3. E. Yolarita and D. W. Kusuma, "Pengelolaan Limbah B3 Medis Rumah Sakit Di Sumatera Barat Pada Masa Pandemi Covid-19," J. Ekol. Kesehat., vol. 19, no. 3, pp. 148-160, 2020.

4. T. Prasetiawan, "Permasalahan Limbah Medis Covid 19 di Indonesia," Info Singk., vol. XII, no. 9, pp. 13-18, 2020.

5. P. Listiningrum, R. S. Firdaus, Q. Annamalia, and A. Mayarana, "Optimasi Regulasi , Fasilitas , dan Public Awareness Penanganan Limbah Infeksius di Masa Pandemi Covid-19," vol. 1, pp. 202-219, 2021.

6. G. Tri Puji Laksono and A. Sari, "Hubungan Pengetahuan, Sikap dan Ketersediaan Sarana Prasarana dengan Perilaku Pengolahan Limbah Medis oleh Petugas Kebersihan," J. Public Heal. Educ., vol. 1, no. 01, pp. 40-47, 2021, doi: 10.53801/jphe.v1i01.16.
7. A. E. Ashari, A. Ganing, Z. Mappau, S. Syamsuddin, and R. H. Saeni, "The Effect of the Emo Demo Method on Knowledge, Attitudes, and Actions in Household Waste Sorting in Mamuju District," vol. 12, no. February, pp. 51-56, 2022.

8. R. H. Saeni, A. E. Ashari, F. Akbar, F. Islam, Ashriady, and A. Mahmud, "Knowledge, Attitude and Practice of Health Workers against COVID-19 Infection When Returning from Work , Mamuju District , Indonesia ," Int. J. Sci. Res., vol. 9, no. 11, pp. 223-227, 2020, doi: 10.21275/SR201102082755.

9. I. M. Apriliani, N. P. Purba, L. P. Dewanti, H. Herawati, and I. Faizal, "Analisis Pengetahuan, Sikap dan Tindakan Tenaga Kesehatan terhadap Pengelolaan Limbah Medis Padat di Puskesmas Kabupaten Konawe Utara," Citizen-Based Mar. Debris Collect. Train. Study case Pangandaran, vol. 2, no. 1, pp. 56-61, 2021.

How to cite this article: Abdul Ganing, Haeranah Ahmad, Ridhayani Adiningsih et.al. Description of waste management of COVID-19 patients without symptoms in self-isolation period Mamuju District. International Journal of Research and Review. 2022; 9(2): 328-331. DOI: https://doi.org/10.52403/ijrr.20220243 